Dorota Guttfeld ${ }^{*}$

\section{Skąd się biorą duchy? Dwa przekłady The Turn of the Screw}

DOI: http://dx.doi.org/10.12775/LC.2017.030

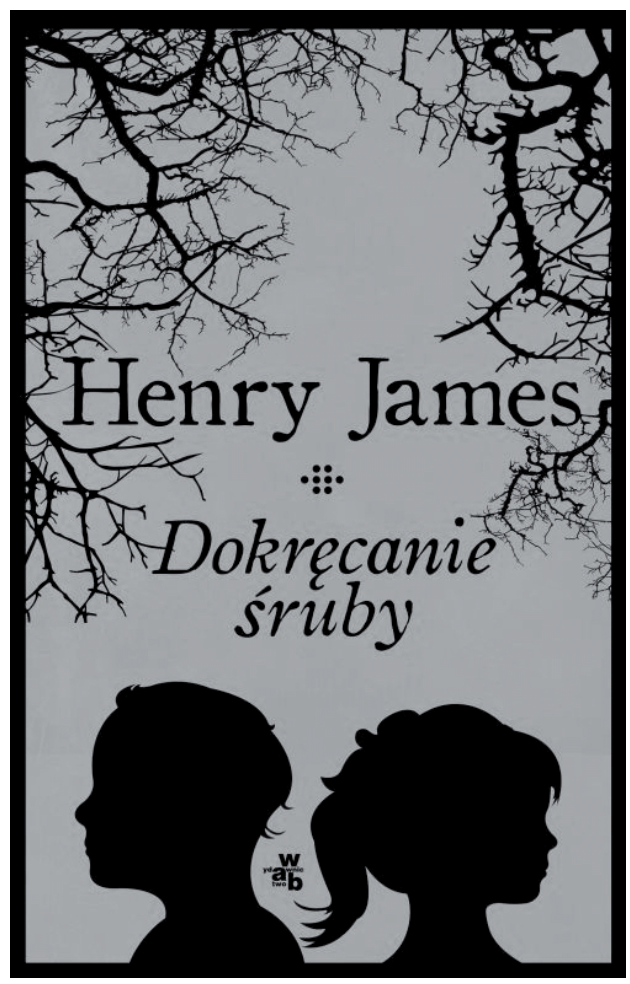

\section{P}

rzekład The Turn of the Screw Henry'ego Jamesa pióra Jacka Dehnela, czyli Dokręcanie śruby opublikowane przez wydawnictwo W.A.B., to druga dostępna po

Adiunkt w Katedrze Filologii Angielskiej na Wydziale Filologicznym Uniwersytetu Mikołaja Kopernika w Toruniu, w pracowni przekładoznawstwa. Interesuje się problemami przekładu literackiego i audiowizualnego oraz anglojęzyczną literaturą fantastyczną. E-mail: gutt@umk.pl. polsku wersja tego tekstu, po $W$ kleszczach lęku Witolda Pospieszały z 1959 roku$^{1}$. Jak zwykle bywa w przypadku serii przekładowych, nowe tłumaczenie stanowi reakcję na poprzednie i stara się poprawić niektóre jego niedociągnięcia i inaczej naświetlić niektóre aspekty oryginału. Po pierwsze, inaczej oczywiście przełożony jest tytuł utworu. Po drugie, przekłady nieco inaczej osadzają opowieść w realiach kulturowych, dobierając formy zwracania się do siebie postaci, sposób traktowania odmian języka i elementów kulturowych. Po trzecie, inaczej są kładzione akcenty w rysunku postaci, na przykład w innym stopniu podkreśla się młody wiek wychowanków guwernantki. Wreszcie pod względem edytorskim zwraca uwagę zastosowanie w przekładzie Dehnela przypisów do tekstu i druku rozstrzelonego, którego użycie pozwala, tak jak w oryginale Jamesa, zaakcentować niektóre partie wypowiedzi i zasugerować ich ukryte znaczenie. Szczegółowa analiza porównawcza obu przekładów wykracza niestety poza ramy prezentowanej recenzji, skupię się więc na jednym tylko aspekcie przekładu Dehnela: podsuwanych czytelnikowi poszlakach co do genezy duchów, na którą tłumacze wydają się mieć odmienne poglądy, co jest kwestią kluczową dla recepcji utworu. Podczas gdy u Pospieszały duchy nabierają dość konwencjonalnego kształtu, Dehnel pozwala czytelnikowi bardziej zwątpić w ich (fizyczne czy metafizyczne) istnienie. Sugeruje raczej emocjonalną niestabilność i niedojrza-

1 Wszystkie cytaty z tłumaczenia W. Pospieszały pochodzą z wydania z 2012 roku: H. James, W kleszczach lęku, przeł. W. Pospieszała, Prószyński i S-ka, Warszawa 2012. Wszystkie cytaty z J. Dehnela: H. James, Dokręcanie śruby, przeł. J. Dehnel, Wydawnictwo W.A.B., Warszawa 2015. Cytaty z wersji oryginalnej za: $\mathrm{H}$. James, The Turn of the Screw and The Aspern Papers, Penguin Books, Londyn 1986. Wszystkie fragmenty oryginalne były również konsultowane z pierwotnym amerykańskim wydaniem, dostępnym $w$ ramach Projektu Gutenberg na stronie http://www.gutenberg. org/files/209/209-h/209-h.htm (dostęp: 15.06.2016). 
łość guwernantki, jej podatność na fantazje i niewiarygodność jako narratorki, a także obecność seksualnego napięcia między guwernantką a wychowankiem.

\section{Emocjonalne rozchwianie}

Pozornie drobna kwestia obecności druku rozstrzelonego przekłada się $\mathrm{w}$ tłumaczeniu Dehnela na wrażenie emfazy, z jaką są wypowiadane (czy wypisywane) poszczególne kwestie narratorki. Podczas gdy u Pospieszały rozmowy wydają się toczyć wolniej, a guwernantka bardziej waży (i niekiedy opatruje wstydliwie cudzysłowami) słowa używane w swojej opowieści, u Dehnela sprawia wrażenie bardziej emocjonalnej i nieprzewidywalnej. U Pospieszały guwernantka to „[s]płoszona, lękliwa dziewczyna”, natomiast Dehnel nazywa ją „a fluttered, anxious girl” - „trwożliwą, rozemocjonowaną panienką", co jest chyba surowszym osądem i skłania do psychologicznej, a nie metafizycznej interpretacji duchów. Narratorka jest tu świadoma swojego dotychczasowego „małego, stłamszonego życia” (31), gdy u Pospieszały wspomina tylko o odchodzącej „nieciekawej, przygasłej młodości” (40); znów wersja Dehnela jest intensywniejsza i sugeruje pewną ciasnotę perspektyw. U Pospieszały wspomina ona $\mathrm{z}$ dystansem swoje „nie nazbyt powabne wdzięki”, gdy u Dehnela są one „przygaszone” (100), a więc kiedyś zapewne $\mathrm{w}$ odczuciu mówiącej istniały $\mathrm{i}$ ich brak może przyczyniać się do frustracji; w oryginale są one zresztą „slighted”, a więc wzgardzone (przez pracodawcę).

Tym osądom u Dehnela towarzyszy większe rozchwianie rejestru języka, którym narratorka się posługuje. Dehnel zachowuje za Jamesem w narracji guwernantki wykrzykniki, wyrażenia rodem z literatury, a także akcentuje niekiedy ślady pewnej dziecinności. Porównajmy pierw- szy opis Bly, które jawi się niekiedy młodej guwernantce jako „castle of romance”, prześcigające "color out of story-books and fairy-tales" (155), tak że zastanawia się ona: „Wasn't it just a story-book over which I had fallen a-doze and a-dream?” (155-156) ${ }^{2}$. U Pospieszały romantyczny zamek „zaćmił baśnie i opowieści. A może była to tylko opowieść, nad którą zdrzemnęłam się i śniłam?” (27), u Dehnela: „romantyczne zamczysko $[\ldots]$ skradło wszelkie kolory klechdom i zbiorom baśni. Czyżbym wpadła, we śnie, rozmarzona, do środka książki z bajkami?" (22) - mamy tu więc bardziej rozbudowaną metaforę, „wpadnięcie” do książki zamiast realistycznego zaśnięcia nad lekturą, a także dziecinne „bajki” i „klechdy”. Podobnie zresztą gdzie indziej „romance” zostaje u Pospieszały „baśnią dziecięcą”, a u Dehnela bardziej egzaltowaną „[p] iosnką dziecięcego pokoju”. Cały fragment u Pospieszały kończy się stwierdzeniem, u Dehnela (tak jak w oryginale) - wykrzyknikiem. Jest to o tyle istotne, że literacka maniera guwernantki jest jednym $\mathrm{z}$ tropów potencjalnie wyjaśniających jej podatność i gotowość na opowieść o duchach, którą sama stworzy. Jednocześnie u Dehnela guwernantka niekiedy wypada $\mathrm{z}$ formy i używa nagle bardziej dosadnego, przyziemnego, pospolitego języka, przypominającego, że ma ona pośledni rodowód i tylko odgrywa rolę pani na włościach, decydującej o losach powierzonych sobie dzieci.

Dla odbioru postaci guwernantki bardzo istotne jest też stosowanie przez Dehnela zdrobnień, co akcentuje uczuciowość, sentymentalizm, ale i emocjonalne rozchwianie narratorki, zwłaszcza kiedy zdrobnienia towarzyszą złośliwym czy w najlepszym razie ambiwalentnym określeniom obojga wychowanków, a z drugiej podkreśla jej niepokojąco niezdrową relację z Milesem, ponieważ

\footnotetext{
${ }^{2}$ W wersji nowojorskiej w pisowni adoze i adream
} 
zdrobnienia zaznaczają na każdym kroku, że jest to dziecko. U Dehnela guwernantka zauważa więc, że pot zrasza „śliczne dziecięce czółko" (169) Milesa, co odpowiada „lovely childish forehead” (dla porównania: u Pospieszały „na czole dziecka”). Jego „twarz nieledwie dotykająca mojej” (u Pospieszały) to u Dehnela "twarzyczka”; gdzie indziej ma „śliczną, rozgorączkowaną twarzyczkę" (173), choć ów bezbronny „biedny, cudowny huncwotek”, stojący w finale opowieści przed starszą kobietą „z rękami w kieszonkach spodni” (160), ma też „charakterek” (u Jamesa po prostu „manner”). Warto zauważyć, że u Pospieszały „[p]oor little exquisite wretch” to „[b]iedne, śliczne niebożątko" rodzaju nijakiego; u Dehnela sytuacja ma zdecydowanie bardziej erotyczny charakter, o czym będzie jeszcze mowa poniżej. Pieszczotliwy, ale i mściwy „charakterek” zdradza satysfakcję guwernantki, która nareszcie ma „huncwotka” w swojej mocy: „Dotychczas dało się zauważyć, że $\mathrm{z}$ wieloma rzeczami radził sobie bez niczyjej pomocy i przyjmowal to za oczywistość, ale kiedy pojął sytuację, w której się znalazł, popadł w potulne milczenie" (160); to ostatnie ma odpowiadać „peaceful silence”. Wreszcie, gdy Miles umiera, u Pospieszały staje jego „małe, biedne serce”, a u Dehnela - „małe serduszko”. Naturalnie u Pospieszały również pojawiają się zdrobnienia, na przykład „tremendous pulse” to „oszalałe bicie serduszka w jego nagle rozpalonym drobnym ciałku" (zwróćmy uwagę na znaczące słowo „oszalałe”), tak jak i u Dehnela, gdzie czuje „nagłą gorączkę, trawiącą to małe ciałko, i galopujące bicie serduszka" (169); jednak u Dehnela jest to wzorzec stosowany przez całą powieść. Powyższa intensyfikacja języka idzie w parze z opisem gestów i zachowań guwernantki. U Pospieszały pisze ona o dzieciach: „[c] wytałam je w ramiona i tuliłam do serca”, by na końcu „[p]rzycisnąć chłopca do siebie” („Press him against me”). U Dehnela natomiast brak uściślenia „w ramiona” sprawia, że gest ten kojarzy się z przemocą („Pod wplywem nieodpartego impulsu, chwytałam je i przyciskałam do serca", 78), a „docisnąć chłopca do siebie” nie tylko sugeruje, że już wcześniej byli z chłopcem do siebie przyciśnięci, ale wręcz, że opiekunka mogła udusić dziecko.

\section{Wiarygodność narracji}

Jeżeli uznać, że w tym przekładzie guwernantka jest osobą o pewnych kompleksach i bujnej wyobraźni ukształtowanej lekturą, która nie do końca panuje nad czynami, językiem i wyobraźnią, a jednocześnie stara się poddać je swoistej cenzurze, warto poszukać w jej wypowiedziach sygnałów świadczących o gotowości do wyobrażenia sobie duchów. Tutaj Dehnelowi udaje się wygrać jedną niejednoznaczność przeoczoną przez Pospieszałę: guwernantka, jeszcze przed pierwszym pojawieniem się ducha, pyta panią Grose o Milesa: „You like them with the spirit to be naughty?" (159). U Pospieszały jest to stwierdzenie bez podtekstów: „Pani woli raczej takich, którzy lubią psocić” (33), natomiast u Dehnela pytanie brzmi wręcz proroczo: „Lubi pani, kiedy mają w sobie psotnego ducha?” (26); to drugie odpowiada i scenariuszowi, w którym Miles drwi sobie z guwernantki, i takiemu, w którym chłopiec rzeczywiście powodowany jest jakąś nieczystą siłą.

Przede wszystkim jednak u Dehnela nie tylko język, ale i sama opowieść niekiedy wymyka się guwernantce spod kontroli, sugerując, że jest czasem nieszczera z panią Grose, ale też z czytelnikiem, a może i samą sobą. Pospieszała traktuje „[t]he appearance was full upon us" jako określenie położenia zjawy, którą dostrzega guwernantka: „[z] awa $[. .$.$] znów zawisła w całej pełni nad$ nami” (220). Tymczasem u Dehnela ujęte 
to jest w sposób sugerujący, że guwernantka twierdzi, jakoby również Miles widział ducha i potwierdzał w ten sposób jej wersję wydarzeń: „ukazała nam się zjawa” (168). Ponieważ za chwilę staje się jasne, że chłopiec niczego nie widzi, ta pierwotna narracja zostaje podważona.

Jeszcze dobitniej rozdźwięk między dwoma fragmentami narracji wybrzmiewa we wcześniejszym sprawozdaniu z pojawienia się ducha panny Jessel, jakie narratorka składa pani Grose. W przeciwieństwie do wcześniejszych scen, otrzymujemy tu dokładny opis zachowania ducha panny Jessel, w którym nie ma wiele białych plam do wypełnienia: kobieta siedzi przy biurku i patrzy na swoją następczynię, ale się nie odzywa. Tymczasem w rozmowie z panią Grose narratorka przytacza, co rzekomo usłyszała od zjawy. Przestraszona albo może wątpiąca pani Grose prosi o potwierdzenie, że guwernantka rozmawiała $\mathrm{z}$ duchem; ta potwierdza: „It came to that”. U Pospieszały na pytanie, czy istotnie zjawa przemówiła, narratorka odpowiada wymijająco, co oczywiście stwarza wrażenie, jakby była nieszczera, a raczej jakby tłumacz starał się zamaskować sprzeczność: „- Czyżby ona się odezwała? Mniej więcej”. U Dehnela guwernantka w bardziej jednoznaczny sposób podważa własne wcześniejsze świadectwo i mija się z prawdą: „To znaczy, że ona przemówiła? Doszło do tego" (120).

\section{Istnienie i natura duchów}

Choć żaden $\mathrm{z}$ tłumaczy nie traci $\mathrm{z}$ oczu wieloznaczności tekstu i oba przekłady można czytać na sposób aparycjonistyczny lub anty-aparycjonistyczny, wydaje się, że u Pospieszały duchy są bardziej konwencjonalne, rodem z opowieści gotyckiej, a u Dehnela - mają raczej charakter psychologiczny i źródło w tłumionych uczuciach i lękach guwernantki. Na takie odczytanie składa się wiele drobnych wyborów translatorskich.

Kiedy guwernantka dostrzega albo wyobraża sobie czyjąś obecność za oknem („to become aware of”, 169), Pospieszała przekłada to trzeźwym „uprzytomniłam sobie” (54), co sugeruje przytomność umysłu, a więc obiektywne istnienie dostrzeganej osoby; ponadto dalszą frazę, „my vision was instantaneous” (169), thumaczy jako „[m]ój wzrok zareagował natychmiast" (54), podkreślając, że postać Quinta jest obiektywnie dostępna zmysłom. Tymczasem u Dehnela guwernantka może zjawę najpierw „wyczuć za oknem" (42), co sugeruje uczucie, a więc jest bardziej ulotne i subiektywne; potem guwernantka obwieszcza: „W jednej chwili ujrzałam wszystko" (42), co musi rodzić pewne podejrzenia i kojarzyć się z wizją, a niekoniecznie świadectwem wzroku.

W kolejnej scenie guwernantka zdaje relację ze spotkania pani Grose. Nie zrozumiawszy się z guwernantką, pani Grose zaprzecza, jakoby odgadła tożsamość nieznajomego: „How can I if you don't imagine?” (172). Pospieszała przekłada to po prostu jako „skoro pani nie ma o tym pojęcia? ” (59). Natomiast u Dehnela, który zasugerował się chyba słowem „imagine”, reakcja pani Grose jest dość wroga i ponownie podważa wiarygodność narratorki: „Skąd mam wiedzieć, że to p a n i sobie tego nie wyobraziła?” (46). Guwernantka istotnie mówi w pewnym momencie o „[m] y infernal imagination", co Dehnel tłumaczy jako „[s] prawka mojej piekielnej wyobraźni” (101); u Pospieszały zaś wspomina ona o „[m]ej przeklętej wyobraźni”, co jest mniej dobitne i mniej jednoznacznie kojarzy się z przybyszami z piekieł. U Pospieszały „grievous fancies” to „żałosna udręka”, u Dehnela - „rozpaczliwe zwidy” (77), co oczywiście sugeruje halucynacje. U Pospieszały guwernantka przyznaje się do „mojego opętania” („my obsession”), co 
wspomaga interpretacje zasadzające się na obecności duchów; u Dehnela mówi o „mojej obsesji” (77), a więc przyznaje, że duchy mogą być wytworem jej wyobraźni. Obsesja ta, jak zaświadczą dalsze przykłady, wydaje się mieć podłoże seksualne, zgodnie z interpretacjami psychoanalitycznymi.

Kiedy już guwernantka przyjmuje, że ma do czynienia $\mathrm{z}$ duchami, u Popieszały są one opisane w sposób bardzo konwencjonalny: jako niematerialne, unoszące się nad ziemią. W omawianym już fragmencie, gdy ducha widzi guwernantka, ale nie mały Miles, u Dehnela czytamy: „ukazała się nam zjawa” (168), podczas gdy Pospieszała interpretuje „upon us” jako „[z]jawa [...] znów zawisła w całej pełni nad nami” (220), co sugeruje, że i teraz, i w trakcie wcześniejszych spotkań unosiła się w powietrzu. Wcześniej dowiadujemy się, znów wskutek nie najlepszego przekładu Pospieszały, że duchy sprawiają wrażenie przezroczystych. W oryginale guwernantka zauważa, że „[t]hey're seen only across, as it were, and beyond", a więc, że na razie duchy nie zbliżają się do dzieci i pokazują się tylko poza zasięgiem, po drugiej stronie szyby, schodów, stawu czy wysoko na wieży. Wypowiedź ta zostaje oddana przez Dehnela jako „tylko w oddali, z boku” (98). Natomiast u Pospieszały brzmi to: „niejako przenikając przez nich wzrokiem lub gdzieś w oddali” (128), znowu więc mamy tu przejrzyste zjawy rodem z powieści gotyckiej.

Wreszcie istotna różnica pojawia się w zakończeniu powieści. Serce Milesa jest tu określone jako „dispossessed”, co Pospieszała tłumaczy jako „biedne serce” (230). Nie jest to przekład zupełnie nietrafiony: idąc tropem „straty”, którą wcześniej zapowiada narratorka, można założyć, że wierzy, iż Miles stracił na zawsze łączność z Quintem, a Quint - prawo własności do chłopca. W pierwszej kolejności i dla większości czytelników jest to jednak po prostu przymiotnik wyrażający współczucie dla nieżyjącego dziecka. Czytelnik zostaje więc w rezultacie bez żadnej wskazówki, która mogłaby podważyć dotychczasową wersję o istnieniu zjaw. Dehnel natomiast interpretuje to słowo w sposób, który można też odnieść do opętania przez duchy: „Małe serduszko uwolnione" (175) spod władzy ducha, ale także metaforycznie: od lęku i coraz bardziej maniakalnych zabiegów guwernantki.

\section{Podtekst erotyczny}

Guwernantka u Dehnela wydaje się dużo bardziej kierować skojarzeniami i impulsami erotycznymi, a groźba, jaką stanowią duchy, wydaje się bardziej seksualna. Guwernantka podejrzewa dziecko o „intercourse” ze zjawami, a więc „utrzymywanie jakiegoś kontaktu” u Pospieszały, ale już o to, że „utrzymuje jakieś stosunki” u Dehnela. Zdaniem guwernantki pani Jessel kontaktuje się z Flora „to get hold of her”: „aby nią owładnąć”, jak przystało na ducha, u Pospieszały, ale u Dehnela - „żeby się do niej dobrać” (65). Pod wypływem panny Jessel dziewczynka wydaje się dojrzewać, co Dehnel zaznacza frazą przyciągającą uwagę do cielesnego aspektu dojrzałości: „Dojrzała, od stóp do głów” („It has made her, every inch of her, quite old"). Wobec zagrożenia ze strony duchów guwernantka wyznacza sobie rolę: „I was a screen”. Słowo to sugeruje ochronę, ale też relację światła i cienia, które odgradza. Pospieszała interpretuje to heroicznie: „Byłam tarczą - miałam stać na straży obojga" (73). U Dehnela chodzi mniej o fizyczną obronę, z jaką kojarzy się tarcza, ale o zachowanie przyzwoitości, o przesłonięcie rzeczy, których dzieci nie powinny widzieć: „Byłam parawanem”. Guwernantka strofuje się przy tym, że nie powinna poddawać się „fancy”. U Pospieszały brzmi to: „[d]ać się ponieść jakimś przesadnym uroje- 
niom", co znowu sygnalizuje trzeźwość umysłu, ale u Dehnela - „ulegać rozbuchanym fantazjom" (69), co sugeruje, że z tej strony właśnie spodziewa się niebezpieczeństwa.

W relacji z Milesem, tak jak ją opisuje Dehnel, guwernantka również wpada w język, który łatwo zinterpretować erotycznie. $\mathrm{O}$ ile u Pospieszały guwernantka mówi „o pokusie” („my temptation”), a więc abstrakcyjnym pojęciu, o tyle u Dehnela jest to bardziej niezwykłe „moje pokuszenie” (88) - a więc kusi, czy też wodzi ją na pokuszenie, coś konkretnego, zewnętrznego, $\mathrm{w}$ tym przypadku prawdopodobnie nieletni wychowanek, przypominający pracodawcę, w którym się zadurzyła. U Dehnela guwernantka sam na sam z Milesem czuje „zażenowanie” (169), co sugeruje jakiś wstyd, grzech, poczucie niestosowności; u Jamesa jest to „uneasiness”, u Pospieszały - „niepokój”, bardziej pasujący do atmosfery powieści grozy.

Najbardziej naładowana podtekstami jest scena nocnej wizyty guwernantki w sypialni Milesa oraz sam final powieści. O tej pierwszej scenie guwernantka pisze: „W tym przelotnym, szorstkim spotkaniu w ciemnościach [...] Wzbudził we mnie uwielbienie" (93). U Pospieszały jest to zaś „krótkie, ostre starcie”, które wywołuje „dreszcz zachwytu". Relacjonując wydarzenia tej nocy, u Pospieszały guwernantka pisze: „wsunęliśmy się do jego pokoiku”, u Dehnela - „wpadliśmy do jego małej sypialni”; ta pierwsza wersja wprawdzie podkreśla, że działo się to ukradkiem, i że lokatorem pokoju było dziecko, ale wersja Dehnela jest bardziej gorączkowa, a „sypialnia” oczywiście konotuje tóżko. Gdy kobieta „dropped, sank upon the edge of the bed", Pospieszała nadaje temu znamiona słabości czy omdlenia („Opadłam na skraj łóżka”), które wymaga zajęcia pozycji siedzącej; u Dehnela wydaje się, że kobieta przyjmuje pozycję leżącą („Runęłam, padając na brzeg łóżka”,
93) i tak już zostaje przez resztę sceny, gdy „I met his kiss”. U Dehnela zostaje przełożone jako „[o]dwzajemniłam jego pocałunek”. U Pospieszały jest to „[o]dpowiedziałam na jego pocałunek", co nie precyzuje formy odpowiedzi; u Dehnela nie ma tu wątpliwości.

Wreszcie, w niezwykle złożonej scenie finałowej, gdy Miles rzekomo stawia czoła zjawie i uwalnia się od niej, omdlewając „z każdym oddechem tego mozołu”, guwernantka obserwuje to $\mathrm{z}$ „moan of joy” i w przyplywie „passion”. To pierwsze to u Pospieszały „tłumiąc radosne szlochanie” i „z jakim uniesieniem”, ale „[z] jękiem radości” i ,jak namiętnie” u Dehnela. W przeciwieństwie do „potwora”, ku któremu guwernantka kieruje finałowe słowa wyzwania u Pospieszały, u Dehnela pojawia się tam żeńska „bestia”. Gramatyczny rodzaj adresata sugeruje, kto $\mathrm{w}$ istocie stanowi zagrożenie, tak z zaświatów (Quint czy raczej poprzedniczka guwernantki panna Jessel, o której obecność dopytuje się półprzytomny Miles), jak w świecie realnym - a więc czy prawdziwą bestią nie jest sama guwernantka, która usiłuje „docisnąć chłopca do siebie”. Różni się też reakcja Milesa i jego ostatnie słowa: u Pospieszały okrzyk „you devil” chłopiec kieruje do Petera Quinta („Ty szatanie”), a więc istnieje możliwość, że on też go widzi. U Dehnela ten krzyk to „ty diablico”, możliwy do odczytania jako oskarżenie pod adresem guwernantki, która wmawia chłopcu istnienie duchów, które są tylko projekcją jej wyobraźni.

\section{Dwa przekłady, wiele odczytań}

Przekład Dehnela daje czytelnikowi nową guwernantkę - niestabilną emocjonalnie dziewczynę, rozdartą pomiędzy językiem egzaltowanym a potocznym, między pożądaniem a zgrozą, między sentymentalną afektacją i wizjami poświęceń, na jakie jest gotowa dla swych wychowanków, 
a satysfakcją z posiadania nad nimi władzy. Ciekawie zapoznać się z tą interpretacją śruba emocji jest tu rzeczywiście dokręcona $\mathrm{w}$ porównaniu $\mathrm{z}$ bardziej stonowanym przekładem Pospieszały. W konstrukcji postaci guwernantki interpretacja Dehnela zgadza się z sugestiami Williama Veedera, upatrującego $\mathrm{w}$ finałowej scenie podświadomego odwetu guwernantki na pracodawcy, przez którego została wzgardzona i wykorzystana, oraz Edmunda Wilsona, który odmalował ją jako sfrustrowaną starą pannę z religijnej protestanckiej rodziny i w rezultacie niebezpieczną histeryczkę, przerażoną własnymi popędami i nie zawsze skutecznie cenzurującą własną narrację.

Henry James, Dokręcanie śruby, przeł. J. Dehnel, Wydawnictwo W.A.B., Warszawa 2015. 